\title{
Response of putative indices of copper status to copper supplementation in human subjects
}

\author{
Claire A. Kehoe, Eithne Turley, Maxine P. Bonham, Jacqueline M. O’Connor, Andrea McKeown, \\ Marian S. Faughnan, James S. Coulter, William S. Gilmore, Alan N. Howard and J. J. Strain* \\ Northern Ireland Centre for Diet and Health (NICHE), University of Ulster, Coleraine BT52 1SA, Northern Ireland
}

(Received 28 January 1999 - Revised 23 September 1999 - Accepted 14 December 1999)

\begin{abstract}
No sensitive functional index is currently available to assess $\mathrm{Cu}$ status in healthy human populations. This study evaluated the effect of $\mathrm{Cu}$ supplementation on putative indices of $\mathrm{Cu}$ status in twelve women and twelve men, aged between 22 and 45 years, who participated in a double-blind placebo controlled crossover study. The study consisted of three 6-week supplementation regimens of $3 \mathrm{mg} \mathrm{CuSO}_{4}, 3 \mathrm{mg} \mathrm{Cu}$-glycine chelate and $6 \mathrm{mg} \mathrm{Cu}$-glycine chelate, each separated by placebo periods of equal length. Women had significantly higher caeruloplasmin oxidase activity $(P<0.001)$, caeruloplasmin protein concentration $(P<0.05)$, and serum diamine oxidase activity $(P<0 \cdot 01)$ at baseline than men. Erythrocyte and leucocyte superoxide dismutase activity, leucocyte cytochrome $c$ oxidase activity, and erythrocyte glutathione peroxidase activity did not respond to $\mathrm{Cu}$ supplementation. Platelet cytochrome $c$ oxidase activity was significantly higher $(P<0 \cdot 01)$, after supplementation with $6 \mathrm{mg} \mathrm{Cu}$-glycine chelate in the total group and in women but did not change in men. Caeruloplasmin oxidase activity was significantly higher $(P<0.05)$, in men after supplementation with $3 \mathrm{mg} \mathrm{Cu}$-glycine chelate, while caeruloplasmin protein concentration was significantly lower in men after supplementation with $6 \mathrm{mg} \mathrm{Cu}$-glycine chelate $(P<0.05)$. Serum diamine oxidase activity was significantly higher after all supplementation regimens in the total group and in both men and women $(P<$ $0 \cdot 01)$. These results indicate that serum diamine oxidase activity is sensitive to changes in dietary $\mathrm{Cu}$ intakes and may also have the potential to evaluate changes in $\mathrm{Cu}$ status in healthy adult human subjects.
\end{abstract}

\section{Copper: Diamine oxidase}

$\mathrm{Cu}$ has long been established as an essential micronutrient for health in both animals and humans. Clinically defined $\mathrm{Cu}$ deficiency in humans, however, remains rare and has only been described in a small number of patients (Danks, 1988). Severe $\mathrm{Cu}$ deficiency, as diagnosed by a marked depression in circulating $\mathrm{Cu}$ and caeruloplasmin concentrations, is accompanied by anaemia and neurological, arterial and myocardial problems (Solomons, 1979; Turnlund, 1994). Sub-optimal $\mathrm{Cu}$ status, however, may be present within populations and remain undetected as it is not associated with any overt clinical symptoms (Milne, 1994), and no suitable, sensitive biochemical index of $\mathrm{Cu}$ status is currently available (Olivares \& Uauy, 1996).

The commonly used putative methods of $\mathrm{Cu}$ status assessment, serum and plasma $\mathrm{Cu}$ protein concentrations and caeruloplasmin oxidase activity, suffer from inherent problems in their interpretation. Serum or plasma $\mathrm{Cu}$ concentrations rise in conditions of stress. Caeruloplasmin is an acute-phase protein and concentrations are increased during inflammation, in smokers and in women using oral contraceptives and hormone replacement therapy (DiSilvestro, 1990; Fisher et al. 1990; Johnson et al. 1992).

Erythrocyte superoxide dismutase (SOD) activity is cited as an alternative, functional means of assessing $\mathrm{Cu}$ status, but may not be sensitive to supplementation and to small changes in $\mathrm{Cu}$ status (Turnlund et al. 1990). Moreover, erythrocyte SOD activity displays a high intra-individual variation (Gallagher et al. 1989), and may be affected by conditions other than Cu status (DiSilvestro, 1988; Nielsen et al. 1990). Other Cu-metalloenzymes, such as platelet cytochrome $c$ oxidase (CCO) activity and serum peptidylglycine $\alpha$-amidating monooxygenase activity, have also been proposed as alternative, sensitive indices of $\mathrm{Cu}$ status (Johnson et al. 1993; Milne \& Forrest, 1996; Prohaska, 1997). Erythrocyte glutathione peroxidase (GPX), although not a $\mathrm{Cu}$-dependent enzyme, appears to have lower activity

\footnotetext{
Abbreviations: CCO, cytochrome $c$ oxidase; CuGC, copper-glycine chelate; DAO, diamine oxidase; GPX, glutathione peroxidase; Hb, haemoglobin; SOD, superoxide dismutase.

* Corresponding author: Professor J. J. Strain, fax +44 (0)1265 324965, email jj.strain@ulst.ac.uk
} 
during $\mathrm{Cu}$ depletion and has been suggested as an alternative to traditional indices of $\mathrm{Cu}$ status (Milne \& Forrest, 1996).

Another $\mathrm{Cu}$-metalloenzyme, which has shown promise as a functional index of $\mathrm{Cu}$ status in human subjects (Jones et al. 1997), is diamine oxidase (DAO). The latter enzyme is responsible for the oxidative deamination of diamines, such as putrescine and cadaverine, and histamine (Wolvekamp \& de Bruin, 1994), and a sensitive colorimetric method for the assessment of serum DAO activity has been described (Takagi et al. 1994). Plasma DAO activity has been reported to be low in a human subject with $\mathrm{Cu}$ deficiency and to be able to differentiate between $\mathrm{Cu}$-deficient and $\mathrm{Cu}$-adequate rats (DiSilvestro et al. 1997; Kehoe et al. 2000). The current study was conducted to investigate the response of several putative indices of $\mathrm{Cu}$ status, including serum DAO activity, to $\mathrm{Cu}$ supplementation in young men and women. Data emanating from the study should indicate the potential of these putative indices as indicators of sub-optimal $\mathrm{Cu}$ status in healthy populations.

\section{Subjects and methods}

\section{Subjects and supplementation regime}

Twenty-four healthy free-living subjects (twelve female and twelve male), aged 22-45 years, were recruited from the staff and student population of the University of Ulster to participate in the double-blind, placebo controlled crossover study. Reasons for exclusion included smokers, those on medication, vitamin or mineral supplements, and the presence of disease such as diabetes or hypertension. The study protocol was reviewed and approved by the Ethical Committee of the University of Ulster. The study consisted of three separate 6-week supplementation regimens of $3 \mathrm{mg} \mathrm{CuSO}_{4}, 3 \mathrm{mg}$ copper-glycine chelate (CuGC), and $6 \mathrm{mg} \mathrm{CuGC/d}$, each separated by placebo periods of equal length. Habitual dietary information was collected from each subject by means of a diet history (Livingstone et al. 1992) by a trained investigator at the beginning and on completion of the study. The records were then analysed using food portion sizes (Crawley, 1992) and nutrient intake calculated using the computer package COMP-EAT (Nutrition Systems, London, UK). The subjects' profiles, including age, $\mathrm{BMI}$, and average $\mathrm{Cu}$ and energy intake at baseline and $\mathrm{Cu}$ and energy intake at the end of the study are shown in Table 1 .

\section{Laboratory procedures}

Blood samples were collected after an overnight fast by antecubital venepuncture into evacuated heparinized, citrated, and plain tubes from each subject at baseline (two samples, 2 weeks apart), and at the end of each separate supplementation or placebo period. Heparinized samples were centrifuged $\left(1800 \mathrm{~g}, 15 \mathrm{~min}\right.$ at $\left.4^{\circ} \mathrm{C}\right)$ and $200 \mu \mathrm{l}$ plasma aliquots were stored at $-80^{\circ} \mathrm{C}$ until analyses for caeruloplasmin oxidase activity and caeruloplasmin protein concentrations. The remaining blood sample was diluted to the original blood volume with $0 \cdot 01 \mathrm{M}-\mathrm{PBS} \mathrm{pH} 7 \cdot 3$ and centrifuged $\left(2000 \mathrm{~g}, 20 \mathrm{~min}\right.$ at $\left.25^{\circ} \mathrm{C}\right)$. The buffy layer was then aspirated from the sample, added to cold saline and centrifuged $\left(2000 \mathrm{~g}, 10 \mathrm{~min}\right.$ at $\left.25^{\circ} \mathrm{C}\right)$, the supernatant discarded and the leucocyte pellet resuspended in $6 \mathrm{ml}$ distilled $\mathrm{H}_{2} \mathrm{O}$. A volume of $2 \mathrm{ml} 3.4 \% \mathrm{w} / \mathrm{v} \mathrm{NaCl}(\mathrm{w} / \mathrm{v})$ was added to the suspension, which was then centrifuged $(2000 \mathrm{~g}, 10 \mathrm{~min}$ at $25^{\circ} \mathrm{C}$ ); this procedure was repeated three times. The resuspended pellet was divided into two, centrifuged $(2000 \mathrm{~g}$, $10 \mathrm{~min}$ at $25^{\circ} \mathrm{C}$ ), and then resuspended in $150 \mu \mathrm{l}$ either $0.01 \mathrm{M}$-PBS buffer, $\mathrm{pH} 7.3$ or $5 \mathrm{mM}$-PBS-EDTA buffer, $\mathrm{pH} 7 \cdot 4$, for leucocyte SOD and CCO determinations respectively. Leucocyte suspensions were stored at $-80^{\circ} \mathrm{C}$ until analysis. Erythrocytes obtained after the aspiration of the buffy layer were resuspended in the original blood volume with $0.9 \% \mathrm{NaCl}$ solution and washed three times by centrifugation $\left(2000 \mathrm{~g}, 10 \mathrm{~min}\right.$ at $\left.25^{\circ} \mathrm{C}\right)$. A $500 \mu \mathrm{l}$ aliquot of washed erythrocytes was stored at $-80^{\circ} \mathrm{C}$ until analysis for haemoglobin $(\mathrm{Hb})$, and for SOD and GPX activities. Citrated blood samples were centrifuged to remove the platelet-rich plasma $\left(160 \mathrm{~g}, 20 \mathrm{~min}\right.$ at $\left.25^{\circ} \mathrm{C}\right)$. This was further centrifuged to obtain the platelet pellet $(730 \mathrm{~g}, 10 \mathrm{~min}$ at $25^{\circ} \mathrm{C}$ ). The pellet was resuspended to the original plasma volume with 5 mM-PBS-EDTA, $\mathrm{pH} 7 \cdot 4$, washed three times, and finally resuspended in $0.6 \mathrm{ml} 5 \mathrm{mM}-\mathrm{PBS}-\mathrm{EDTA}, \mathrm{pH} 7 \cdot 4$. Analyses for $\mathrm{CCO}$ activity and protein concentrations were performed on the fresh platelet extractions. Serum samples were prepared by centrifuging clotted whole blood samples $\left(2000 \mathrm{~g}, 15 \mathrm{~min}\right.$ at $\left.4^{\circ} \mathrm{C}\right)$. These were stored at $-80^{\circ} \mathrm{C}$ until analysis. All frozen samples were analysed in batch and in duplicate within 10 months of completion of the study.

Protein concentrations were determined using the method of Bradford (1976) (Bio-Rad Laboratories, Herts., UK), with bovine serum albumin as standard. The determination of $\mathrm{Hb}$ concentrations was performed using the cyanmethaemoglobin method. Erythrocytes $(40 \mu \mathrm{l})$ were diluted

Table 1. Subject characteristics and dietary profiles

(Mean values and standard errors of the mean)

\begin{tabular}{|c|c|c|c|c|}
\hline & \multicolumn{2}{|c|}{ Men $(n 9)$} & \multicolumn{2}{|c|}{ Women $(n$ 10) } \\
\hline & Mean & SEM & Mean & SEM \\
\hline Age (years) & $31 \cdot 3$ & 8.23 & 33.1 & 8.23 \\
\hline BMI & $23 \cdot 2$ & 3.47 & $25 \cdot 0$ & 1.88 \\
\hline Energy (kJ/d, week 0) & 10280 & 640 & 8150 & 410 \\
\hline Energy (kJ/d, week 39) & 11480 & 570 & 8810 & 530 \\
\hline Dietary copper $(\mathrm{mg} / \mathrm{d}$, week 0$)$ & 1.38 & 0.1 & 1.08 & 0.1 \\
\hline Dietary copper ( $\mathrm{mg} / \mathrm{d}$, week 39) & 1.59 & 0.1 & 0.98 & 0.1 \\
\hline
\end{tabular}


with $20 \mathrm{ml}$ ISOTON (Coulter Electronics Ltd, Luton, Beds., UK), in a plastic vial (Sterilin, BDH Ltd, Poole, Dorset, UK). The samples were mixed by inversion and six drops ZAPOGLOBIN (Coulter Electronics Ltd) added. The samples were left for $5 \mathrm{~min}$ at room temperature and the haemoglobin concentration was determined within $1 \mathrm{~h}$, in $\mathrm{g} / \mathrm{dl}$, using a haemoglobinometer (Coulter Electronics Ltd).

Plasma caeruloplasmin oxidase activity was determined by a modification of the method by Henry et al. (1960), using $p$-phenylenediamine dihydrochloride (Sigma Aldrich Co Ltd, Poole, Dorset, UK) as substrate and measuring the rate of oxidation of $p$-phenylenediamine dihydrochloride at $37^{\circ} \mathrm{C}$. Analysis was performed on the Cobas Fara automatic analyser (Roche, Basel, Switzerland). Caeruloplasmin protein concentrations were measured turbidimetrically using a modification of the method of Calvin \& Price (1986). Using dilution buffer, $\mathrm{pH} 7 \cdot 3$, plasma was prediluted $1: 41(\mathrm{v} / \mathrm{v})$ and mixed with excess rabbit anti-human caeruloplasmin (Dako, Glostrup, De nmark). The resulting antibody-antigen complex was stabilised with a phosphate buffer containing polyethylene glycol 6000 (BDH Ltd). The absorbance at $340 \mathrm{~nm}$ was measured on the Cobas Fara automatic analyser (Roche), and concentrations (U/l) were determined from a standard curve calculated using a human serum protein calibrator (Dako).

The activity of SOD was determined on the Cobas Fara automatic analyser (Roche) by a modification of the method of Jones \& Suttle (1981), using a commercial kit, RANSOD. (Randox Laboratories, Co. Antrim, Northern Ireland). Activity of SOD was expressed perg $\mathrm{Hb}$ in erythrocytes, and per $\mathrm{mg}$ protein in leucocytes.

Erythrocyte GPX activity was assessed by a modification of the method of Paglia \& Valentine (1967) using a commercially available kit, RANSEL (Randox Laboratories). The assay was performed on the Cobas Fara automatic analyser (Roche). GPX activity was expressed as U/g Hb.

The assay for CCO activity (U/g protein) was performed on fresh platelet suspensions and leucocytes using a modification of the method described by Smith (1955). Immediately prior to running the assay, $0.2 \mathrm{ml}$ of the platelet suspension was sonicated at an amplitude of $10 \mu \mathrm{m} / 6 \mathrm{~s}$. The substrate cytochrome $c$ (Sigma) was reconstituted in $0 \cdot 1 \mathrm{M}-\mathrm{K}_{2} \mathrm{PO}_{4}$ buffer, $\mathrm{pH} 7 \cdot 0$, and reduced with sodium dithionite (Sigma). The excess sodium dithionite was removed by separation using a G-25 Sephedex column (Pharmacia Biotech, Uppsala, Sweden), and the final concentration was standardised at $57.7 \mathrm{mM}( \pm 0 \cdot 3 \%)$ to ensure a concentration of $50 \mu \mathrm{M}$ in the final reaction mix. The CCO activity was determined on the Cobas Fara automatic analyser (Roche) by measuring the loss of ferrocytochrome $c$ at $550 \mathrm{~nm}$ at $37^{\circ} \mathrm{C}$. A CCO (Sigma) buffered suspension, reconstituted in PBS buffer, was used as an in-house control for the CCO assay.

Serum DAO activity was determined on the Cobas Fara automatic analyser (Roche), using a modification of the method described by Tagaki et al. (1994). A substrate solution $(36 \mathrm{mmol} / \mathrm{l})$ was prepared by dissolving cadaverine dihydrochloride (Sigma) in a $25 \mathrm{mmol}$ 1,4-piperazinediethane sulphonic acid (PIPES) buffer/l (pH 7.2). The substrate solution, $130 \mu \mathrm{l}$, was incubated at $37^{\circ} \mathrm{C}$ for
5 min, after which $30 \mu$ l serum sample and $20 \mu$ l PIPES buffer were added, mixed and incubated for $30 \mathrm{~min}$ at $37^{\circ} \mathrm{C}$. The colour solution was prepared by dissolving $10 \mu \mathrm{mol}$ DA-67 (Wako Chemicals USA, Inc., Richmond, VA, USA) in $100 \mathrm{ml} 25 \mathrm{mmol} 2$-( $N$-morpholino)ethanesulfonic acid (MES) buffer/l (Sigma). Just before the addition of the colour solution to the assay, $6 \mathrm{U} / \mathrm{ml}$ peroxidase and $5 \mathrm{U} / \mathrm{ml}$ ascorbate oxidase (Sigma) were added to the colour solution. The development of methylene blue was initiated by the addition of $150 \mu \mathrm{l}$ colour solution to the reaction mixture and the rate of colour development at $668 \mathrm{~nm}$ was measured over $12 \mathrm{~min}$ and quantified (U/l) by a standard curve prepared using DAO (Sigma) standards.

\section{Data analysis}

All data were analysed using the SPSS 6.1 for Windows statistical package (SPSS Inc., Chiago, IL, USA) and performed at each crossover only on subjects who completed both supplementation and placebo regimens. The presence of carryover was tested for at each crossover as outlined by Senn (1993). The effect of $\mathrm{Cu}$ treatment compared to placebo was analysed at each crossover by independent $t$ tests of 'period differences' between supplementation sequences, a method that adjusts data for any possible period effects. One-way ANOVA was used to examine differences between the sexes at baseline. Unavoidable absences of subjects at particular blood sampling times account for differences in crossover numbers.

\section{Results}

Women had significantly higher plasma caeruloplasmin oxidase activity (725 (SE 59.1) U/l; $P<0.001$ ), plasma caeruloplasmin protein concentration (0.24 (SE 0.2) g/l; $P<0.05$ ), and serum DAO activity (0.24 (SE 0.29) U/l; $P<0.01$ ) than men (552 (SE 44.4) U/l, 0.16 (SE 0.01) g/l and $0 \cdot 10$ (SE 0.13) U/l respectively) at baseline. Erythrocyte and leucocyte SOD, and erythrocyte GPX showed no changes in activity in the total group or in male and females separately after any $\mathrm{Cu}$ supplementation regimen (Table 2). Platelet $\mathrm{CCO}$ activity was significantly higher following supplementation with $6 \mathrm{mg} \mathrm{CuGC}$ than during the placebo regimen $(P<0.01)$ in the total group and in women but not in men (Table 2). Significant carryover effects were observed in platelet CCO activity in women during crossover with $3 \mathrm{mg}$ CuGC $(P<0.05)$ and in leucocyte CCO activity in men during each crossover: $3 \mathrm{mg} \mathrm{CuSO}_{4}(P<0.05), 3 \mathrm{mg} \mathrm{CuGC}$ $(P<0.01), 6 \mathrm{mg} \mathrm{CuGC}(P<0.05)$ (Table 2). No significant difference was observed in the response of plasma caeruloplasmin oxidase activity and caeruloplasmin protein concentration to any $\mathrm{Cu}$ supplementation regimen in the total group or in women. Men showed a significant increase in plasma caeruloplasmin oxidase activity after supplementation with $3 \mathrm{mg} \mathrm{CuSO}_{4}(P<0 \cdot 05)$, and plasma caeruloplasmin concentration was significantly decreased after supplementation with $6 \mathrm{mg}$ CuGC $(P<0.05)$. Serum DAO activity increased significantly during all three $\mathrm{Cu}$-supplementation regimens. This increase was observed in the total group and in both men and women separately $(P<0 \cdot 01)$ (Table 2). 
Table 2. Response of putative indices of copper status to different levels of copper supplementation in the total group, and in men and women separately

(Mean values with standard errors)

\begin{tabular}{|c|c|c|c|c|c|c|c|c|c|c|c|c|c|c|c|}
\hline & \multicolumn{5}{|c|}{ Crossover 1} & \multicolumn{5}{|c|}{ Crossover 2} & \multicolumn{5}{|c|}{ Crossover 3} \\
\hline & \multicolumn{2}{|c|}{$3 \mathrm{mg} \mathrm{CuSO}_{4} / \mathrm{d}$} & \multicolumn{2}{|c|}{ Placebo 1} & \multirow[b]{2}{*}{$n$} & \multicolumn{2}{|c|}{$3 \mathrm{mg} \mathrm{CuGC/d}$} & \multicolumn{2}{|c|}{ Placebo 2} & \multirow[b]{2}{*}{$n$} & \multicolumn{2}{|c|}{$6 \mathrm{mg} \mathrm{CuGC/d}$} & \multicolumn{2}{|c|}{ Placebo 3} & \multirow[b]{2}{*}{$n$} \\
\hline & Mean & SE & Mean & SE & & Mean & SE & Mean & SE & & Mean & SE & Mean & SE & \\
\hline \multicolumn{16}{|c|}{ Erythrocyte superoxide dismutase (U/g Hb) } \\
\hline Total & 1166 & 38 & 1077 & 33 & 23 & 1068 & 41 & 1032 & 29 & 21 & 1042 & 39 & 1049 & 48 & 19 \\
\hline Men & 1107 & 50 & 1115 & 45 & 12 & 1123 & 77 & 1038 & 45 & 9 & 1096 & 53 & 1138 & 32 & 8 \\
\hline Women & 1022 & 55 & 1035 & 48 & 11 & 1028 & 42 & 1040 & 38 & 12 & 1003 & 55 & 984 & 31 & 11 \\
\hline \multicolumn{16}{|c|}{ Leucocyte superoxide dismutase (U/g protein) } \\
\hline Total & 1.04 & 0.09 & 1.23 & 0.14 & 23 & 1.81 & $0 \cdot 16$ & 1.89 & 0.24 & 20 & 1.66 & $0 \cdot 19$ & 1.81 & 0.20 & 20 \\
\hline Men & 0.98 & 0.13 & $1 \cdot 15$ & 0.14 & 12 & 1.98 & 0.27 & $2 \cdot 39$ & 0.49 & 8 & 2.09 & 0.25 & $1 \cdot 76$ & 0.27 & 9 \\
\hline Women & $1 \cdot 11$ & 0.13 & $1 \cdot 32$ & 0.26 & 11 & $1 \cdot 70$ & 0.20 & 1.55 & 0.18 & 12 & $1 \cdot 31$ & 0.24 & 1.85 & 0.29 & 11 \\
\hline \multicolumn{16}{|c|}{ Platelet cytochrome $c$ oxidase (U/g protein) } \\
\hline Total & $7 \cdot 10$ & 0.50 & 6.76 & 0.31 & 17 & $7 \cdot 46$ & 0.20 & 7.35 & 0.38 & 18 & $7 \cdot 35^{\star \star}$ & 0.25 & 6.33 & $0 \cdot 15$ & 14 \\
\hline Men & 6.95 & 0.65 & 6.99 & 0.42 & 10 & $7 \cdot 65$ & 0.23 & $7 \cdot 11$ & 0.65 & 8 & $7 \cdot 71$ & 0.51 & 6.54 & 0.27 & 6 \\
\hline Women & $7 \cdot 32$ & 0.81 & $6 \cdot 67$ & 0.46 & 7 & $7 \cdot 31$ & 0.30 & $7.55 \dagger$ & 0.44 & 10 & $7 \cdot 08^{\star *}$ & 0.19 & $6 \cdot 17$ & 0.17 & 8 \\
\hline \multicolumn{16}{|c|}{ Leucocyte cytochrome $c$ oxidase (U/g protein) } \\
\hline Total & 1.96 & 0.29 & 2.31 & 0.37 & 21 & 4.37 & 1.26 & $4 \cdot 26$ & 1.44 & 17 & 3.97 & 0.60 & 4.56 & 0.77 & 20 \\
\hline Men & $2 \cdot 17$ & 0.36 & $2 \cdot 17 \dagger$ & 0.64 & 10 & 2.84 & 0.85 & $3.36 \dagger \dagger$ & 0.68 & 8 & 4.90 & 1.03 & $4.29 \dagger$ & 1.07 & 9 \\
\hline Women & $1 \cdot 77$ & 0.47 & $2 \cdot 16$ & 0.42 & 11 & $5 \cdot 61$ & $2 \cdot 13$ & 4.98 & 2.57 & 9 & $3 \cdot 21$ & 0.66 & 4.79 & $1 \cdot 14$ & 11 \\
\hline \multicolumn{16}{|c|}{ Erythrocyte glutathione peroxidase (U/g Hb) } \\
\hline Total & $45 \cdot 6$ & 2.0 & 46.2 & 1.9 & 23 & 47.5 & $2 \cdot 4$ & $47 \cdot 4$ & $2 \cdot 1$ & 21 & $48 \cdot 2$ & $2 \cdot 2$ & 48.4 & $2 \cdot 4$ & 20 \\
\hline Men & $42 \cdot 6$ & 3.0 & 44.4 & $3 \cdot 1$ & 12 & $48 \cdot 7$ & 4.0 & $47 \cdot 0$ & 3.3 & 9 & $47 \cdot 3$ & $3 \cdot 1$ & $46 \cdot 8$ & $4 \cdot 1$ & 9 \\
\hline Women & $48 \cdot 9$ & $2 \cdot 4$ & $48 \cdot 6$ & $2 \cdot 1$ & 11 & $46 \cdot 6$ & $3 \cdot 2$ & $47 \cdot 6$ & $2 \cdot 8$ & 12 & $49 \cdot 0$ & $3 \cdot 2$ & $46 \cdot 8$ & $3 \cdot 0$ & 11 \\
\hline \multicolumn{16}{|c|}{ Caeruloplasmin oxidase (U/I) } \\
\hline Total & 637 & $42 \cdot 4$ & 627 & $34 \cdot 0$ & 22 & 621 & $34 \cdot 1$ & 621 & $42 \cdot 0$ & 21 & 601 & $35 \cdot 6$ & 612 & $35 \cdot 2$ & 20 \\
\hline Men & 545 & $36 \cdot 9$ & 566 & $25 \cdot 2$ & 11 & $537^{\star}$ & 29.4 & 527 & $28 \cdot 2$ & 9 & 546 & $32 \cdot 8$ & 535 & 31.4 & 9 \\
\hline Women & 729 & $67 \cdot 0$ & 687 & $59 \cdot 1$ & 11 & 639 & $48 \cdot 9$ & 691 & $64 \cdot 1$ & 12 & 647 & $56 \cdot 7$ & 676 & $52 \cdot 3$ & 11 \\
\hline \multicolumn{16}{|c|}{ Caeruloplasmin protein (g/l) } \\
\hline Total & 0.19 & 0.01 & 0.19 & 0.01 & 22 & 0.21 & 0.01 & 0.21 & 0.02 & 21 & 0.20 & 0.01 & 0.21 & 0.01 & 20 \\
\hline Men & 0.17 & 0.01 & 0.18 & 0.01 & 11 & $0.18^{*}$ & 0.01 & 0.16 & 0.01 & 9 & $0.18^{*}$ & 0.01 & 0.19 & 0.01 & 9 \\
\hline Women & 0.21 & 0.02 & 0.21 & 0.02 & 11 & 0.23 & 0.02 & 0.25 & 0.03 & 12 & 0.22 & 0.02 & 0.22 & 0.02 & 11 \\
\hline \multicolumn{16}{|c|}{ Serum diamine oxidase (U/I) } \\
\hline Total & $1 \cdot 34^{\star *}$ & 0.31 & 0.30 & 0.29 & 16 & $1.63^{\star \star}$ & 0.48 & 0.44 & $0 \cdot 11$ & 20 & $2 \cdot 00^{\star \star}$ & $0 \cdot 11$ & 0.89 & 0.22 & 17 \\
\hline Men & $0.87^{\star \star}$ & 0.27 & 0.27 & $0 \cdot 17$ & 7 & $1 \cdot 21^{\star *}$ & 0.36 & 0.47 & 0.01 & 9 & $1.55^{\star \star}$ & 0.49 & 0.44 & 0.28 & 7 \\
\hline Women & $1.64^{\star \star}$ & 0.47 & 0.33 & $0 \cdot 17$ & 9 & $1.92^{\star \star}$ & 0.41 & 0.42 & 0.23 & 11 & $2 \cdot 37^{\star \star}$ & 0.79 & $1 \cdot 16$ & 0.32 & 10 \\
\hline
\end{tabular}

CuGC, copper-glycine chelate; Hb, haemoglobin.

Mean value was significantly different from placebo group, ${ }^{\star} P<0.05,{ }^{* \star} P<0.01$

Significant carryover effect, $\uparrow P<0.05, \dagger \dagger P<0.01$.

$\ddagger$ For details of subjects and procedures see Table 1 and p. 152.

\section{Discussion}

The findings from the current study indicate that serum DAO activity shows a marked response to $\mathrm{Cu}$ supplementation in healthy subjects. This increase in DAO activity was evident in both men and women and after each $\mathrm{Cu}$-supplementation period. These results suggest that serum DAO activity is responsive to $\mathrm{Cu}$ intake and has the potential to be a sensitive indicator of $\mathrm{Cu}$ status in human subjects.

Serum DAO activity, however, is raised in pregnancy (Kusche et al. 1974), uraemia (Tam et al. 1979), kidneydialysis patients (DiSilvestro et al. 1997) and after gastrointestinal damage (Wolvekamp \& deBruin, 1994), and is reportedly lowered in Crohn's disease and coeliac disease (Bayless et al. 1981). Tagaki et al. (1994) have questioned the significance of lowered serum DAO activity in these latter diseases as basal activity of serum DAO is very low in normal healthy individuals. We also found very low serum DAO activity in our subjects at baseline and at the end of the placebo periods. It is possible, therefore, that the rise in serum DAO activity after $\mathrm{Cu}$ supplementation is simply reflecting alterations in gut integrity caused by ingestion of the supplement. Our subjects, however, did not report any adverse side effects during the study. Moreover, DiSilvestro et al. (1997) have found significantly lower plasma DAO activity in $\mathrm{Cu}$-deficient rats and low plasma DAO activity in a woman with spontaneous $\mathrm{Cu}$ deficiency who responded to parenteral $\mathrm{Cu}$ repletion by increases in plasma caeruloplasmin protein concentration and caeruloplasmin oxidase activity accompanied by an increase in plasma DAO activity. Data from our laboratory show that marginally $\mathrm{Cu}$-deficient rats have significantly lower plasma DAO activity and liver $\mathrm{Cu}$ content but no differences in other indices of $\mathrm{Cu}$ status compared with $\mathrm{Cu}$-adequate controls (Kehoe et al. 2000). 
Taken together, these findings imply that serum or plasma DAO activity can also respond to changes in $\mathrm{Cu}$ status as well as to alterations in intestinal structural integrity.

Serum DAO activity was higher in women than men at baseline. This $\mathrm{Cu}$-metalloenzyme showed similar sex differences to the well-documented higher caeruloplasmin oxidase activity and protein concentrations in women compared with men (Fisher et al. 1990; Johnson et al. 1992; Milne \& Johnson, 1993). It is unlikely that the small increase observed in plasma caeruloplasmin activity after $3 \mathrm{mg} \mathrm{CuGC}$ or the small decrease in caeruloplasmin protein after $6 \mathrm{mg}$ $\mathrm{CuCG}$ in our male subjects is of physiological significance. No changes were noted in plasma caeruloplasmin protein concentrations in sixteen healthy infants after supplementation with $9.1 \mu \mathrm{mol} \mathrm{Cu} / \mathrm{d}$ for the first year of life (Salmenpera et al. 1989) and in seven adults receiving $10 \mathrm{mg} \mathrm{Cu}-$ gluconate for 12 weeks (Pratt et al. 1985). In contrast to the present study, in a similar placebo-controlled intervention, increases in serum caeruloplasmin protein concentration were observed in eight healthy male subjects after supplementation with $\mathrm{Cu}$-gluconate $(2 \mathrm{mg} \mathrm{Cu} / \mathrm{d})$ for 6 weeks (Medeiros et al. 1991).

The significant increase in platelet CCO activity (only after $6 \mathrm{mg} / \mathrm{d}$ CuGC supplementation) seen in our subjects, and which was largely driven by increased activity in women, is apparently at variance with the reported sensitivity of this enzyme as an indicator of $\mathrm{Cu}$ status based on depletion studies in women (Milne \& Forrest, 1996), and men (Turnlund et al. 1997) where both mononucleated cell and platelet $\mathrm{CCO}$ activities were analysed. The significant carryover that was observed in several of the crossover regimens in the current study with this index, however, is a major confounding problem. In the absence of any effective method of adjusting data for carryover, this phenomenon can only be noted (Senn, 1993), and limits the interpretation of results of CCO activity, as the carryover effect may mask a possible treatment effect in the current study.

The responses of $\mathrm{Cu}$-metalloenzymes, such as erythrocyte SOD activity, appear to be sensitive indicators of changes in $\mathrm{Cu}$ status in depletion studies (Milne \& Forrest, 1996; Turnlund et al. 1997), but do not seem to respond to supplementation in healthy subjects. For example, Medeiros et al. (1991) found no significant difference in SOD activity of men supplemented with $3 \mathrm{mg} \mathrm{Cu}$-gluconate/d for 6 weeks when compared to controls. Our observation that supplementation with different $\mathrm{Cu}$ compounds and at different $\mathrm{Cu}$ concentrations did not alter SOD activity is in agreement with these findings. It should be noted that mean dietary $\mathrm{Cu}$ intakes in our study were $1.38-1.59 \mathrm{mg} / \mathrm{d}$ for men and $1.08-0.98 \mathrm{mg} / \mathrm{d}$ for women and supplementation with $6 \mathrm{mg}$ $\mathrm{CuGC}$ would increase intakes of $\mathrm{Cu}$ to greater amounts than those usually reported in western diets (Klevay et al. 1993).

In conclusion, the results of our study indicate that serum DAO activity increases after $\mathrm{Cu}$ supplementation in both healthy men and women and has the potential to be a sensitive functional indicator of $\mathrm{Cu}$ status in human subjects. As serum DAO activity has not been investigated extensively as an indicator of $\mathrm{Cu}$ status, future experimentation should further elucidate the specificity of the enzyme to changes in $\mathrm{Cu}$ status and the health consequences, if any, of low serum DAO activity.

\section{Acknowledgements}

Support from the European Commission, Grant CT95-0813 FOODCUE, Ministry of Agriculture Fisheries and Food Grant A181(AN0511) are gratefully acknowledged. Claire Kehoe acknowledges receipt of a Co-operative Award in Science and Technology (CAST); sponsored by The Howard Foundation, Whitehill House, Granham's Road, Great Shelford, Cambridge CB2 5JY, UK. Supplements were supplied by Thomson \& Joseph Ltd, Norwich.

\section{References}

Bayless TM, Luk GD, Baylin SB \& Thomas ME (1981) Decreased plasma diamine oxidase levels in Crohn's disease and celiac disease. Gastroenterology 80, 1106.

Bradford MM (1976) A rapid and sensitive method for the quantitation of microgram quantities of protein utilizing the principle of protein-dye binding. Analytical Biochemistry 72, 248-254.

Calvin J \& Price CP (1986) Measurement of alpha 1 antichymotrypsin by immunoturbidity. Annals of Clinical Biochemistry 23, 296-299.

Crawley H (1992) Food Portion Sizes, 3rd ed. London: H.M. Stationery Office.

Danks DM (1988) Copper deficiency in humans. Annual Review of Nutrition 8, 235-257.

DiSilvestro RA (1988) Influence of copper intake and inflammation on rat serum superoxide dismutase activity levels. Journal of Nutrition 118, 474-479.

DiSilvestro RA (1990) Influence of dietary copper, copper injections and inflammation on rat serum ceruloplasmin activity levels. Nutrition Research 10, 355-358.

DiSilvestro RA, Jones AA, Smith D \& Wildman R (1997) Plasma diamine oxidase activities in renal dialysis patients, a human with spontaneous copper deficiency and marginally copper deficient rats. Clinical Biochemistry 30, 559-563.

Fisher PWF, L'Abbé MR \& Giroux A (1990) Effects of age, smoking, drinking, exercise and estrogen use on indices of copper status in healthy adults. Nutrition Research 10, 1081-1090.

Gallagher SK, Johnson LK \& Milne DB (1989) Short-term and long-term variability of indices related to nutritional status. I: $\mathrm{Ca}, \mathrm{Cu}$. Fe, Mg, and Zn. Clinical Chemistry 35, 369-373.

Henry RJ, Chiamori N, Jacobs SL \& Segalove M (1960) Determination of caeruloplasmin oxidase in serum. Proceedings of the Society for Experimental Biology and Medicine 104, 620-624.

Johnson PE, Milne DB \& Lykken GI (1992) Effects of age and sex on copper absorption, biological half-life, and status in humans. American Journal of Clinical Nutrition 56, 917-925.

Johnson WT, DuFault SN \& Thomas AC (1993) Platelet cytochrome $c$ oxidase activity is an indicator of copper status in rats. Nutrition Research 13, 1153-1162.

Jones A, DiSilvestro RA, Coleman M \& Wagner TL (1997) Copper supplementation of adult men: effects on blood copper enzyme activities and indicators of cardiovascular disease risk. Metabolism 46, 1380-1383.

Jones DG \& Suttle NF (1981) Some effects of copper deficiency on leucocyte function in cattle and sheep. Research in Veterinary Science 31, 151-156.

Kehoe CA, Faughnan MS, Gilmore WS, Coulter JS, Howard AN \& Strain JJ (2000) Plasma diamine oxidase activity is greater in copper adequate than copper marginal or copper deficient rats. Journal of Nutrition 130, 30-33.

Klevay LM, Buchet JP, Bunker VW, Clayton BE, Gibson RS, Medeiros DM, Moser Veillon PBL, Payterson KY, Taper LJ \& Wolf WR (1993) Copper in the western diet (Belgium, Canada, UK and USA). In Trace elements in Man and Animals-TEMA 8, 
pp. 207-210 [M Anke, D Meisser and CF Mills, editors]. Gersdorf, Germany: Verlag Media Touristik.

Kusche J, Trotha UV, Muhlberger G \& Lorenz W (1974) The clinical-chemical application of the NADH test for the determination of diamine oxidase activity in human pregnancy. Agents in Action 4/3, 188-189.

Livingstone BME, Prentice AM, Coward WA, Strain JJ, Black AK, Davies PSW, Stewart CM, McKenna PG \& Whitehead RG (1992) Validation of estimates of energy intake by weighed dietary record and diet history in children and adolescents. American Journal of Clinical Nutrition 56, 29-35.

Medeiros DM, Milton A, Brunett E \& Stacy L (1991) Copper supplementation effects on indicators of copper status and serum cholesterol in adult males. Biological Trace Element Research 30, 19-35.

Milne DB (1994) Assessment of copper nutritional status. Clinical Chemistry 40, 1479-1484.

Milne DB \& Forrest FH (1996) Effects of a diet low in copper on copper-status indicators in postmenopausal women. American Journal of Clinical Nutrition 63, 358-364.

Milne DB \& Johnson PK (1993) Assessment of copper status: effect of age and gender on reference ranges in healthy adults. Clinical Chemistry 39, 883-887.

Nielsen FH, Milne DB, Mullen LM \& Gallagher SK (1990) Dietary sulfur amino-acids, and genetic make-up or interindividual variation affect the response to copper depletion. Journal of Trace Element and Experimental Biology 3, 281-296.

Olivares M \& Uauy R (1996) Copper as an essential nutrient. American Journal of Clinical Nutrition 63, 791S-796S.

Paglia DE \& Valentine WN (1967) Studies on the quantitative and qualitative characterization of erythrocyte glutathione peroxidase. Journal of Laboratory Clinical Medicine 70, 158-169.

Pratt WB, Omdahl JL \& Sorenson JRJ (1985) Lack of effects of copper gluconate supplementation. American Journal of Clinical Nutrition 42, 681-682.
Prohaska JR (1997) Response of rat cuproenzymes to variable dietary copper. Journal of Nutritional Biochemistry 8, 316-321.

Salmenpera L, Siimes MA, Nanto V \& Perheentupa J (1989) Copper supplementation: failure to increase plasma copper and ceruloplasmin concentrations in healthy infants. American Journal of Clinical Nutrition 50, 843-847.

Senn S (1993) The AB/BA design with normal data. In Cross-over Trials in Clinical Research, pp. 31-60 [Y Barnett, editor]. Chichester: J. Wiley \& Sons.

Smith L (1955) Spectrophotometric assay of cytochrome $c$ oxidase. In Methods of Biochemical Analysis, pp. 427-434. New York, NY: J. Wiley \& Sons.

Solomons NW (1979) On the assessment of zinc and copper nutriture in man. American Journal of Clinical Nutrition 32, 856-871.

Takagi K, Nakao M, Ogura Y, Nabeshima T \& Kunii A (1994) Sensitive colorimetric assay of serum diamine oxidase. Clinical Chimica Acta 226, 67-75.

Tam CF, Kopple JD, Wang M \& Swendseid ME (1979) Diamine oxidase activity in plasma and urine in uremia. Nephron 23, 2327

Turnlund JR (1994) Copper. In Modern Nutrition in Health and Disease, 8th ed., pp. 231-241 [ME Shils, JA Olson and M Shike, editors]. Philadelphia, PA: Lea \& Febiger.

Turnlund JR, Keen CL \& Smith RJ (1990) Copper status and urinary and salivary copper in young men at three levels of dietary copper. American Journal of Clinical Nutrition 51, 658664.

Turnlund JR, Scott KC, Peiffer GL, Jang AM, Keyes WR, Keen CL \& Sakanashi TM (1997) Copper status of young men consuming a low-copper diet. American Journal of Clinical Nutrition 65, 72-78.

Wolvekamp MC \& deBruin RW (1994) Diamine oxidase: an overview of historical, biochemical and functional aspects. Digestive Diseases 12, 2-14. 